\title{
Factors Affecting Customer Satisfaction of Mobile Services in Yemen
}

\author{
Has hed Ahmed Nasser. M ${ }^{1, *}$, Salniza Bt Md. Salleh ${ }^{1}$, Hamid mahmood Ge laidan ${ }^{2}$ \\ ${ }^{1}$ Othman Yeop Abdullah Graduate School of Business, Universiti Utara Malaysia, Sintok, 06010, Malay sia \\ ${ }^{2}$ School of business management,college of business, university utara Malaysia
}

\begin{abstract}
The aim of this study is to find out the customer's satisfaction with Yemeni Mobile service providers. This study examined the relationship between perceived quality, perceived value, customer expectation, and corporate image with customer satisfaction. The result of this study is based on data gathered online fro 118 academic staff in public universities in Yemen. The study found that the relationship between perceived value, perceived quality and corporate image have a significant positive influence on customer satisfaction, whereas customer expectation has positive but without statistical significance.
\end{abstract}

Keywords Perceived Quality, Perceived Value, Customer Expectation, Corporate Image, Customer Satisfaction, Mobile Service Providers in Yemen

\section{Introduction}

In a very limited period, mobile te lecommun ications have become an increasingly needed service with a very high penetration rate in most countries. With the extensive mobile telecommunications usage, the mobile services market is now recognized as the most competitive part of the telecommun ications sector. The emergence of a competitive markets has led to lowerprices, which has also resulted in the widespread use, greater variety and quality of mobile services.

Mobile telecommunications technologies have developed over successive generations. The first generation (1G) appeared in the 1950's. The second generation (2G) or GSM technology was used extensively, but was challenged globally by the next (third) generation (3G) technologies. This sequence of generations is characterized by increasing capacity and richer content of the message. Further penetration of $3 \mathrm{G}$ depends on the integration of telecommunications and multimedia services, which turned out to be more complicated than most experts predicted[1]. Since 1990, the telecommunications sector has become dynamic and vital to the economic development of industrialized nations. This is a result of the tremendous technical progress, as well as the emergence of many network operators and the ensuing intense competition. These factors, in turn, are the result of the abolition of monopoly rights, which were enjoyed main ly by workers in

\footnotetext{
* Corresponding author:

hashed88@gmail.com (Hashed Ahmed Nasser.M)

Published online at http://journal.sapub.org/economics

Copyright (C) 2012 Scientific \& Academic Publishing. All Rights Reserved
}

the states of public telecommunications networks. At the beginning of 2004, there were over 1.3 billion cell-phone users. Over the next three years, the demand for mobile services is predicted to grow at an average annual rate of $9.1 \%[2]$.

Mobile services have grown contrary to the experts' expectations. Mobile telecommunications services everywhere in the world have always been in strong demand. In the 1990's, the rapid growth rate was accompanied by critical changes in the telecommunications markets. The usual way to call someone has changed from using the telephone booth or a fixed telephone line to using a personal phone that is easily carried everywhere we go. This growth is also responsible for the intense competition between service operators in the telecommunications industry. This competition is forcing the operators to adopt effective strategies in order to satisfy the customers.

Mobile service providers should understand the importance of customer satisfaction and loyalty while planning strategies for user retention. The remarkable diffusion of mobile services has outperformed experts' expectations. From a marginal industry "in the shadow" of other telecommun ications providers (e.g., Fixed lines and the Internet), it has become a leading segment, providing commodity services. As such, the penetration of mobile phones is almost twice as high as that of personal computers. While only $9.9 \%$ of the world's population owned PCs in 2002, 19\% already poss essed cellphones [3].

Hence, today's customers are more concerned about having high quality telecommunication services that satisfy them. They have a range of expectations of the telecommunication services. Quality of service is becoming increasingly important to differentiate between competing 
businesses in the telecommunications sector. The fiercely competitive marketplace is characterized by similarly priced, look-alike services from a variety of mobile services' providers; big market share will be gained by the ones that provide excellent service quality. Delivering quality to customers is essential to a company's well-being because it results in retaining the current customers, getting new customers, less customers lost, , more protection from price competition, and fewer mistakes requiring the company to redo its goods/services[4].

Furthermore telecommunications industry is one of the many services in the industrial field, characterized by high customer contact with individually customized service solutions, where customer satisfaction has become an increasing focus of research. The issue of how to improve customer satisfaction is very important for mobile communications operators. Therefore, it is believed that customer satisfaction plays a significant role in the telecommunications market competition.

While competition in mobile markets is currently developing rapidly, the level of market competition differs among different countries. As a matter of fact, even in developed countries, there are clear differences in terms of competitiveness. Despite the change from a state-owned regulated monopoly to full competition, mobile operators are often the strongest market players in the markets. The mobile operators have a significant market power until now in many countries.

Competition exists between the mobile operators to retain their existing customers and to reach maximum number of new customers. Because of this competition, customer satisfaction plays an important role in the retention of the existing customers in the telecommun ications industry. This is done by offering a wide range of high quality services that are efficient, cost effective and competitive to Yemeni customers.

This study is conducted in Yemen. The Republic of Yemen is a country located on the Arabian Peninsula in Southwest Asia with an estimated population of more than 26 million people.

\section{Telecommunications Industry in Yemen}

The widespread use of mobile phone technologies by society can be clearly seen across all walks of life in Yemen. Nowadays, the new generations look further to have updated mobile phone service, as they prefer to finish their work faster. Hence, the mobile phone is one of the ways to expedite tasks. Therefore, mobile phones seem to be a very important device for almost all people.

Between 2004-2006, Yemen improved its mobile communications services as the number of mobile telephone subscribers jumped from 1.483 million in 2004 to 3.201 million in 2006. Competition between private sector companies operating in this field led to the expansion of mobile telephone service coverage to include all governorates and diversified services. Competition in service prices, therefore, increased public demand on these services, The Mobile telephone service-to-inhabitants ratio increased from $15 \%$ in 2000 to $15.3 \%$ in 2006 ,[5].

The mobile telecommunications sector in Yemen consists of one public sector provider (Yemen Mobile) and three private companies (Sabafon, MTN and GSM Y). After granting two private companies concessions to operate the mobile phone network, i.e. Sabafon and MTN, a third company was licensed by the end of 2005 to operate the GSM system. In July 2007, the name of this company was announced (Ynet), and it entered the market in 2007. Yemen Mobile, a fourth company, has been working since 2004 as a mobile phone operator (with CDMA technology). It was established under the sponsorship of the Yemen Public.

Sabafon is the first GSM operator in Yemen, which began in February 2001 this company declares it covers $68 \%$ of Yemen's population, and will continue its efforts to roll out into new places and regions in Yemen. The Yemen Sabafon company which specializes in the operation of GSM networks is the first company to offer mobile services in Yemen to two million subscribers [6].

Yemen Mobile is a CDMA 2000 network provider founded in Yemen, 2004 by the Yemen Ministry of Telecommunications and is considered the first CDMA network operator in the Middle East. Yemen Mobile CDMA system is based on the HUAWEI Technologies. The number of subscribers in January 2010 was around 2.6 million[7].

MTN in Yemen describes itself as "the leader in telecommunications in Africa and the Middle East" and as of early 2007, is active in 21 countries. It was founded in Yemen in February 2001 and the nu mber of subscribers up to May 2006 was more than 1.250 .000 subscribers with coverage by 600 stations until the end of 2006, [8].

GSM Y is another mobile telecommunications company launched in Yemen is GSM Y. A recently established enterprise backed by capital from Saudi Arabia, Kuwait, the United Arab Emirates, and Syria, it promises to have a major impact on the market which it entered in 2007, [9].

Yemeni customers looking to know what the weather's going to be like. Or there's a traffic jam on the $5 \mathrm{p}$ m? Mobile services bring the consumers a whole range of information via their phone - from news and sport, to travel and weather updates.

\section{Problem Statement}

Due to lack of modern technologies in Yemen telecommunications systems, the few existing telecommunications marketers are strategically challenged on what best approach should be applied so as to efficiently provide services and retain profitable customers both within and outside the Yemen telecommunications industry[10]. Similarly,[11]; emphasized some of the current issues that Sabafon, which is one of the biggest telecommunications 
companies in Yemen, is facing, specifically in achieving the desired level of customer satisfaction. This is despite Sabafon's efforts in establishing a strong dynamic and flexible organization to serve and benefit the people of Yemen[11].

As a sequel to the above practical issues in the Yemen telecommunications industry, it is important to emphasize that accomplishing customer satisfaction has been argued as the primary goal for most service firms in order to achieve a long term relationship with both the present and potential customers at a profit[12].[13], indicated that customer satisfaction issues are an important theoretical as well as a practical issue for research on marketers and consumers. These arguments are also in line with researchers like[14] who empirically established that customer satisfaction has had a direct influence on the company's market share through which it could improve its profits.

However[15], conducted a study on Swedish firms and stated that there is a significant relationship between expectations, perceived value and customer satisfaction. Furthermore,[15],[16], mentioned that perceived value is an important factor of customer satisfaction. This call has been supported by several researchers such as[17], and they indicated in their research of mobile services in Canada that the degree of perceived value is a necessary factor affecting customer satis faction.

Similarly,[18], explained that the gap that may exist between the customers' expected and perceived service quality is an important factor of customer satisfaction. Moreover, image refers to the brand name and the kind of association customers get from the product or service / company[19].[20], indicated that image is an important component of customer satisfaction. For the companies, image is a result of being reliable, qualified and innovative, having contributions to society, and adding reputation to its customers.

The Mobile telecommunications services sector is an emerging industry in Yemen. Arguably, existing evidence has shown that very few studies have been conducted on this topic in Yemen[21]. Investigating this topic would provide both the academics and practitioners ideas about Yemeni customer satisfaction in the Teleco mmun ication Sector.

Based on the highlighted earlier gaps with respect to the previous researches, this study is a response to the calls by previous researchers on the need to investigate the important factors such as perceived quality, perceived value, customer expectation, and corporate image that could truly affect customer satisfaction in Yemeni mobile phone service companies.

\section{Research Objective}

1) To investigate the relationship between perceived quality and the customer satis faction.

2) To investigate the relationship between perceived value and the customer satisfaction.
3) To investigate the relationship between customer expectation and the customer satisfaction.

4) To investigate the relationship between corporate image and the cus tomer satis faction.

\section{Literature Review}

\subsection{Customer Satisfaction}

In today's competitive mobile service industry, customers have many options available. Factors that enable a telecommunications company to attract and retain a customer should be studied seriously[21]. Mobile service providers should start to search for effective and creative ways to attract, retain or foster a stronger relationship with customers.

The increase in technology has required mobile operators to provide customers with new features in their connection so that existing customers can be retained. The relationship between service quality and perceived value should be brought into focus by the service providers. They should be curious about customer satisfaction. Customer satisfaction must be continuously appraised, especially after customers have been using the service for a period of time. Different factors have different in fluence on customers. These factors should be taken into consideration in order to formulate strategies for customer satisfaction. Yemeni mobile service operators must focus on customer satisfaction as a serious marketing strategy[22].

Customer satis faction is the perceived degree of fulfilment of expectations and the actual services provided by mobile phone service providers and large investments are being made to increase the level of customer satis faction, but only in an increase in resources alone cannot lead to increased levels of customer satisfaction. Thus, there must be other factors leading to improved customer satisfaction, as pointed out by[23]. They opined that customer satisfaction is achieved through good qualitative and quantitative services. These way of services must meet and satisfy the customer requirements in order to maximize the level of customer satisfaction that in turn can lead to customer loyalty.[24] found that more customized, specific or better-tailored services that meet customer's needs and expectations would lead to a high level of customer satisfaction. Value-added services offered by mobile services providers can increase both customer satis faction and total usage, which in turn can reduce churn rate, increase revenue and repurchase of entire services in future[25].

Customer satisfaction is totally focused on the services provided to and perceived by the customers; if there is a high similarity between perceived and provided services, than the customer satis faction level is very high. That directly leads to high customer loyalty for mobile service providers or vice versa. There are many benefits for a firm that has a high customer satisfaction level: they get a high market share and become capable of keeping and maintaining customers[26]. The American Customer Satisfaction Index ACSI indicates 
how much customers are satisfied and how well their expectations are met. This construct evaluates an overall satisfaction level of customers, fulfilment of their expectations, and company's performance versus the ideal provider.

[27], wrote in their book that "companies now have big investment in database marketing, relationship management and customer planning to move closer to their customers". [28], mentioned that "achieving customer satisfaction is the main goal for most service firms today".

Increasing customer satisfaction has been shown to directly affect companies' market share, which leads to improved profits, positive recommendation, and lower marketing expenditures[29],[30]; and greatly impact the corporate image and survival[18]. Customer satisfaction, as a process, is defined as an evaluation between what was received and what was expected[31],[32],[33]; emphasizing the perceptual, evaluative and psychological processes that contribute to customer satisfaction [34].

However,[35], noted that the progression of satisfaction definitions concentrates on the antecedents to satisfaction rather than satisfaction itself. Customer satisfaction to some organizations is a key to success; the reason here is to check the ability of their service to satisfy as many customers as they can, so that they can be the market leaders in their respective fields. Many organizations followed the strategy of customer satisfaction and became living legends, e.g. AT\&T, Vodafone, Orange, Nokia, Sony, etc. Every company mentioned here are an innovator and a market leader in any one or two of their products and services. Based on the above discussion, customer satisfaction can be defined as a customer's overall experience to an evaluation to the service which is received from the mobile company provider.

\subsection{Perceived Quality}

In recent years, there has been a growing importance of service quality and customer satisfaction in business and academia alike.[36]; determined that the balance of power between service quality and customer satisfaction with an emphasis on these two constructs is the concept that is different from the view of customers.

It is also observed that customer satisfaction is also dependent on perceived quality and has a positive role towards this dependence. Hence, proper care should be taken while formulating any long term policy for customer satisfaction. At least for building profits, customer satisfaction is a main determinant[37]. Furthermore, perceived quality is the limit up to which the product or service provided the necessary needs of customer with more satisfaction.[38]; indicated that both service quality and customer satisfaction have some things in common; satisfaction is generally observed as a wider concept than service quality assessment; thus, perceived service quality is a component of customer satisfaction.

Perceived quality is then based on market evaluation of recent consumption experience. This construct appraises customization and reliability of a given product or service. Customization is the degree to which a product or service meets a customer's requirements, and re liability is the degree to which a firm's offering is reliable, standardized and free from defects[39].

[40]; reported that service quality is a casual antecedent of customer satisfaction, because service quality is viewed at a transactional level and satisfaction is viewed to be an attitude.[41],[38]; reported that the service quality divisions are related to overall service quality and or customer satisfaction.[39]; expressed that satis faction is a consequence of service quality.[42], argued that there is a causal relationship between service quality and satisfaction, and that the perceptions of service quality affect the feelings of satisfaction. Perceived quality is defined as the rank to which a product or service provides key customer requirements (customization) and how reliably these requirements are delivered (reliability)[43]. Perceived quality is often measured through three measures: overall quality, perceived reliability, and the extent to which a product or service meets the cus tomer's needs. Customer perceptions of quality are the single greatest predictor of customer satisfaction. Based on the above discussion perceived quality can be defined as the overall judgment of the service quality which is received fro $m$ the company mobile provider.

\subsection{Perceived Value}

Mobile services providers are investing a lot but still there are mismatches in the actual and perceived value of the customers; a latest survey by[44], revealed that although there is progress, nonetheless, perceived value from the telecom players has the lowest score. This has risen from $71 \%$ in 2005 to $76 \%$ in 2006 .

However, the pertinent question is how and to what extent are mobile service providers charging their customers and providing value. All customers expect benefits in terms of value. An intention to adopt or reject a mobile service appears to be determined to a greater extent by perceived benefits than by perceived barriers[45]. As the companies give higher value to customers in terms of charges, then the satisfaction level gets higher that leads to customer loyalty.

[46]; defined perceived value as "the consumer's overall assessment of the usefulness of a product based on perceptions on what is received and what is given." Companies are able to increase customer satisfaction by creating customer value through many ways, such as by providing customers with the comparative net value, effectiveness, efficiency, and differentiation of services, which can be delivered via logistics[47]. Both times and places of service delivery are indicated to be important dimensions of customer perceived value, and when or where the service is delivered should be determined by customers rather than by companies.

The impact of value on customer satisfaction was studied by[48] defined customer perceived value as "an interactive, 
preferential and relative experience." Results of their research reveal that both utilitarian and hedonic values are positively related to customer satis faction. Perceived value is measured through two questions: overall price given quality and overall quality given price. Although perceived value is important for the (first) purchase decision, it usually has somewhat less impact on satisfaction and repeat purchase.

Moreover,[49]; stated that customers who perceive that they receive value for money are more satisfied than customers who do not perceive they receive value for money. [15],[50]; [16], find that PV is the significant determinant of customer satisfaction.[17], in their investigation of mobile services in Canada, suggested that the degree of PV is a key factor affecting customer satisfaction. Based on the above discussion perceived value can be defined as overall of service quality related to the price paid and service received.

\subsection{Customer Expectation}

Expectations are the consequences of previous experience with the company's products or services. This raises customer expectations for overall quality, in product and service quality, and for fulfilment of personal needs. Customer expectations' construct is anticipated to have a direct and positive relationship with customer satisfaction [15],[51]. On the other hand,[52], reported that the relationship between customer expectation and customer satisfaction had a weak and non-significant relationship in some other previous CSI Customer satis faction studies, such as ACSI, ECSI[53]. In this study customer expectation can be defined as the level of customer expectation from the company mobile provider.

\subsection{Corporate Image}

The image construct appraises the fundamental image of the company. Image applies to the brand name and the type of association customers get from the product/company [19].[20]; indicated that image is an important component of customer satis faction. For the companies, image is a result of being reliable, professional and inventive, having contributions to society, and adding good reputation to its customers. It is expected that image has a positive effect on customer satisfaction.[19]; posited that corporate image, through a filtering effect, impacts a customer's evaluation of service quality, value, and satisfaction. In other words, corporate image creates a halo effect on customer satisfaction. Consumers who develop a positive mental scheme with a brand will tend toward high customer satisfaction through a halo effect where all things associated with the brand are similarly valued. Corporate image is a result of a customer's overall consumption experiences [54]. The same mechanism is available for overall satisfaction. Since customer satisfaction and corporate image measures are collected simultaneously, customers' consumption experiences, which can be summarized as satisfaction, naturally affect the evaluations of corporate image[53]. In this study corporate image can be defined as the image of the company service provider which that influence the customer perception.

\section{Research Methodology}

A scientific manner of planning, executing, and discussing important results is essential for doing any study, regardless of which fields are being investigated, such as managerial and social fields. Therefore, this chapter defines the research design, theoretical framework, population samples, instrument, data collection procedures and the techniques of data analysis for examining the factors that affect customer satisfaction with mobile services in Yemen. The said factors are perceived quality, perceived value, customer expectation and corporate image.

\subsection{Research Design}

This study is descriptive and hypotheses testing in natural. This study aimed to examine the factors that affect the customer satisfaction among the customers of mobile services. This study was cross-sectional and involved the hypothesis testing based on what has been developed in the framework. The hypotheses testing was explained the relationship between the independent and dependent variables. Finally, data was collected using online survey method where questionnaires were used to collect information.

\subsection{Research Framework}

DV

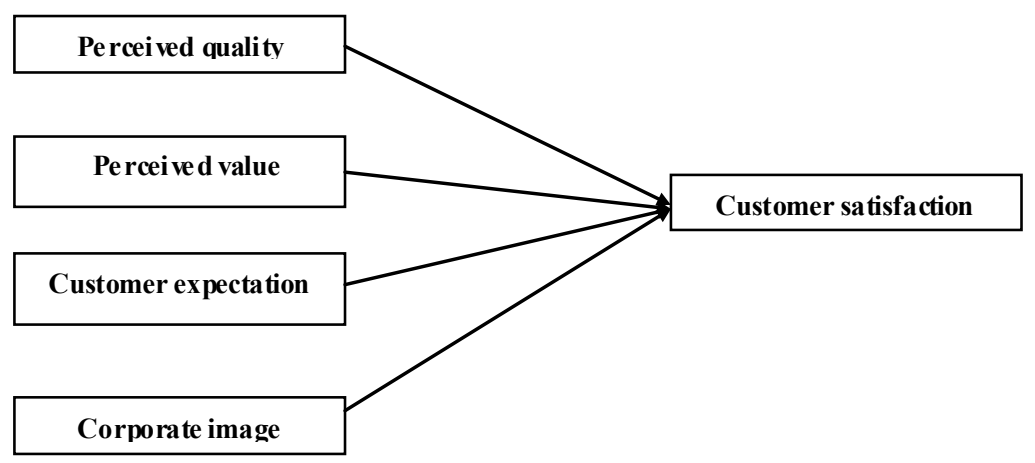

Figure 1. Research Framework 


\subsection{Hypothesis Development}

In this study, the hypothes is has been selected based on the literature review mentioned above to describe the relationship among those variables that influences on customer satisfaction.

1. There is a positive/significant relationship between the perceived quality and customer satisfaction.

2. There is a positive/significant relationship between the perceived value and customer satis faction.

3. There is a positive/significant relationship between the customer expectations and customer satis faction.

4. There is a positive/significant relationship between the corporate image and customer satisfaction.

\subsection{Me as urement of Variable}

This survey was involving a sample target of customers of mobile services in the Republic of Yemen.

\subsection{Population and Sample}

The population in this study is all academic staff working with public universities in Yemen. They are around 5800 academic staff. Therefore, the unit of analysis is the academic staff. In addition, the questionnaires were randomly distributed to 361 respondents by using the stratified random sampling. According to[55] the sample size is enough regarding the population size.

\subsection{Data Collection Techni que}

The questionnaires were personally distributed and administered by the researcher to the respondents. This method was possible since the researcher's access to the respondents, was by sending the survey online, and then receiving the response immed iately a fter the respondents had completed the survey. The questionnaire is divided into two parts: part one contains the demographic factors with eleven questions whereas part two includes the items of variables with sixteen questions.

Table 1. Instrument Development

\begin{tabular}{|c|c|c|c|c|c|}
\hline & Variables & & Items & Authors & $\begin{array}{l}\text { Scale } \\
\text { Likert }\end{array}$ \\
\hline \multirow{3}{*}{ DV } & \multirow{3}{*}{$\begin{array}{l}\text { Customer } \\
\text { satisfaction }\end{array}$} & 1 & Overall satisfaction. & \multirow{3}{*}{ Fornell (1996) } & \multirow{3}{*}{5} \\
\hline & & 2 & $\begin{array}{l}\text { Expectancy disconfirmation (Performance falls short of your } \\
\text { expectations or exceeded your expectations). }\end{array}$ & & \\
\hline & & 3 & $\begin{array}{l}\text { Performance versus the customer's ideal product or service in the } \\
\text { cat egory. }\end{array}$ & & \\
\hline \multirow{3}{*}{ IV } & \multirow{3}{*}{$\begin{array}{l}\text { Perceived } \\
\text { Quality }\end{array}$} & 1 & Overall evaluation of quality experience (post-purchase) & \multirow{3}{*}{ Fornell (1996) } & \multirow{3}{*}{5} \\
\hline & & 2 & $\begin{array}{l}\text { Evaluation of customization experience, or how well the product fit the } \\
\text { customer's personal requirements (post-purchase) }\end{array}$ & & \\
\hline & & 3 & $\begin{array}{l}\text { Evaluation of reliability experience, or how often things have gone } \\
\text { wrong (post-purchase) }\end{array}$ & & \\
\hline \multirow{2}{*}{ IV } & \multirow{2}{*}{ Perceived Value } & 1 & Rating of Quality compared to Price. & \multirow{2}{*}{ Fornell (1996) } & \multirow{2}{*}{5} \\
\hline & & 2 & Rating of Price compared to quality. & & \\
\hline \multirow{3}{*}{ IV } & \multirow{3}{*}{$\begin{array}{l}\text { Customer } \\
\text { Expectation }\end{array}$} & 1 & Overall expectation of quality (pre-purchase) & \multirow{3}{*}{ Fornell (1996) } & \multirow{3}{*}{5} \\
\hline & & 2 & $\begin{array}{l}\text { Expectation regarding cust omization, or how well the product and } \\
\text { service fits the customer's personal requirements (pre-purchase) }\end{array}$ & & \\
\hline & & 3 & $\begin{array}{l}\text { Expectation regarding reliability, or how often things would go wrong } \\
\text { (pre-purchase. }\end{array}$ & & \\
\hline \multirow{5}{*}{ IV } & \multirow{5}{*}{ Corporate Image } & 1 & It can betrusted in what it says and does. & \multirow{5}{*}{$\begin{array}{l}\text { Bayol et al. } \\
\quad(2000)\end{array}$} & \multirow{5}{*}{5} \\
\hline & & 2 & It is stable and firmly established. & & \\
\hline & & 3 & It has a social contribution for the society. & & \\
\hline & & 4 & It is concerned with customers. & & \\
\hline & & 5 & It is innovative and forward looking. & & \\
\hline
\end{tabular}




\subsection{Data Analysis Technique}

The data was analyzed by using Statistical Package for the Social Sciences (SPSS) to get the outcome of the result of descriptive statistics and inferential analysis. Descriptive and explanatory (inferential) analysis was used to analyze data collected from the respondents. Descriptive study takes into account the mean, standard deviations and percentage. Furthermore, inferential study takes into account the correlation and multi-regression analysis. Correlation analys is is used in order to achieve the objectives of the study as well as to measure the significance of linear bivariate between the variables [56]. In addition, multi-regression analysis is used to achieve the objectives of this study as well as to identify the relationship between the dependent and independent variables from the aspects of level, direction and the strength of the relationship.

Table 2. Profiles of Respondents ( $\mathrm{N}=118)$

\begin{tabular}{|c|c|c|c|}
\hline \multicolumn{2}{|l|}{ Variables } & \multirow{2}{*}{$\begin{array}{c}\text { Fre quency } \\
109 \\
\end{array}$} & \multirow{2}{*}{$\begin{array}{c}\text { Percentage (\%) } \\
92.4 \\
\end{array}$} \\
\hline Gender & Male & & \\
\hline & Female & 9 & 7.6 \\
\hline \multirow{3}{*}{ Education } & Degree & 39 & 33.1 \\
\hline & Master & 43 & 36.4 \\
\hline & $\mathrm{PhD} / \mathrm{DBA}$ & 36 & 30.5 \\
\hline \multirow{2}{*}{ Using more than one phone } & Yes & 46 & 39.0 \\
\hline & No & 72 & 61.0 \\
\hline \multirow{4}{*}{ Phone brand } & Nokia & 96 & 81.4 \\
\hline & Sony Ericson & 9 & 7.6 \\
\hline & I phone & 5 & 4.2 \\
\hline & Others & 8 & 6.8 \\
\hline \multirow{2}{*}{ Color screen } & Yes & 110 & 93.2 \\
\hline & No & 8 & 6.8 \\
\hline \multirow{2}{*}{ Camera } & Yes & 101 & 85.6 \\
\hline & No & 17 & 14.4 \\
\hline \multirow{4}{*}{ Current provider } & Sabafon & 40 & 33.9 \\
\hline & MTN & 41 & 34.7 \\
\hline & Yemen Mobile & 34 & 28.8 \\
\hline & GSM Y & 3 & 2.5 \\
\hline \multirow{4}{*}{ Purchase phone } & Less than one year & 18 & 15.3 \\
\hline & $1-3$ years & 58 & 49.2 \\
\hline & $3-6$ years & 19 & 16.1 \\
\hline & 6 years above & 23 & 19.5 \\
\hline \multirow{4}{*}{ Connect to the provider } & Less than one year & 23 & 19.5 \\
\hline & $1-3$ years & 46 & 39.0 \\
\hline & 3-6 years & 25 & 21.2 \\
\hline & 6 years above & 24 & 20.3 \\
\hline \multirow{2}{*}{ Is this first mobile phone } & Yes & 20 & 16.9 \\
\hline & No & 98 & 83.1 \\
\hline \multirow{2}{*}{ Voice call } & Not use & 26 & 22.0 \\
\hline & Use & 92 & 78.0 \\
\hline \multirow{2}{*}{ Download games } & Not use & 113 & 95.8 \\
\hline & Use & 5 & 4.2 \\
\hline \multirow{2}{*}{ Play games } & Not use & 83 & 70.3 \\
\hline & Use & 35 & 29.7 \\
\hline \multirow{2}{*}{ Text messaging(SMS, MMS) } & Not use & 6 & 5.1 \\
\hline & Use & 112 & 94.9 \\
\hline \multirow{2}{*}{ Picture messaging (picture exchange) } & Not use & 73 & 61.9 \\
\hline & Use & 45 & 38.1 \\
\hline \multirow{2}{*}{ Voicemail } & Not use & 115 & 97.5 \\
\hline & Use & 3 & 2.5 \\
\hline \multirow{2}{*}{ Download ringtones and icons } & Not use & 114 & 96.6 \\
\hline & Use & 4 & 3.4 \\
\hline \multirow{2}{*}{ Voice activated dialing } & Not use & 114 & 96.6 \\
\hline & Use & 4 & 3.4 \\
\hline \multirow{2}{*}{ Wireless Internet access } & Not use & 105 & 89.0 \\
\hline & Use & 13 & 11.0 \\
\hline Roaming (using your mobile phone & Not use & 106 & 89.8 \\
\hline in a foreign country) & Use & 12 & 10.2 \\
\hline Information services (e.g., news, & Not use & 114 & 96.6 \\
\hline stock quotes, weather, etc.) & Use & 4 & 3.4 \\
\hline
\end{tabular}




\section{Findings \& Data Analysis}

This section presents the findings of the study as well as all the findings obtained through statistical analysis. This research is based on descriptive study and hypothesis testing. It begins with preparation, data screening, and profiles of respondents which give an idea of how the data looks like. This is followed by the frequency output which alerts the researcher about the possible inaccuracy in the data. This study also includes correlation and multiple-regression. Finally, the hypothesis testing is followed with a summary. The research completely relied on SPSS 14 as the enabling description for data analyses for qualitative analysis. In general, the findings obtained from the survey revealed the interesting relationships of the variables, thus the relevant results are presented in this chapter.

\subsection{Preliminary Testing}

Preliminary data testing involves preparation and screening the data, that would convert the raw data from a questionnaire to useable data in SPSS. This data was obtained through the online survey; the normality is meeting the requirement and no missing values exist. Furthermore, the data was not further transformed or treated.

\subsection{Res pondents Profiles}

The questionnaires were distributed online to staff in 8 universities. The subjects were 109 (92.4\%) male and nine $(7.6 \%)$ female respondents. The analysis shows that, respondents' level of education was: 39 (33.1\%) with undergraduate degree, 43 (36.4\%) master's degree, and 36 $(30.5 \%)$ with PhD and DBA. As shown in the table 2, in terms of the frequency of using more than one phone, $46(37 \%)$ responded they used more than one, and $72(61 . \%)$ used only one phone. Regarding the phone brand, the finding shows that $96(81.4 \%)$ used Nokia brand, nine $(7.6 \%)$ used Sony Ericson brand, five (4.2\%) used Iphone brand, and eight $(6.8 \%)$ used other brands .

\subsection{Descriptive Analysis}

Table 3. Descriptive Statistics of Variables

\begin{tabular}{|c|c|c|c|c|c|}
\hline \multicolumn{2}{|c|}{ Variable Name } & Minimum & Maximum & Mean & Std. Dev \\
\hline $\mathbf{Y}$ & $\begin{array}{c}\text { Customer } \\
\text { Satisfaction }\end{array}$ & 1.00 & 5.00 & 2.9746 & .68376 \\
\hline $\mathbf{X I}$ & $\begin{array}{c}\text { Customer } \\
\text { expectation }\end{array}$ & 1.00 & 5.00 & 3.3785 & .73175 \\
\hline $\mathbf{X 2}$ & Perceived quality & 1.00 & 5.00 & 3.2655 & .76057 \\
\hline $\mathbf{X 3}$ & Perceived value & 1.00 & 5.00 & 3.0339 & .87883 \\
\hline $\mathbf{X 4}$ & Corporate image & 1.80 & 4.60 & 3.1051 & .64355 \\
\hline
\end{tabular}

Descriptive statistics such as mean and percentage were used to measure the percentage of variables and also used to describe the mean of dependent and independent variables. Table 3 below shows mean of customer satisfaction for the variables;

The mean value of customer satisfaction was 2.9746; this reveals that the customer satisfaction was moderate as the minimum value was 1.00 , and the maximum value was 5.00 . In addition, there are small differences between the values of customer satisfaction as indicated by the low value of the standard deviation (.68376).

Based on the table above, the mean value of customer expectation was 3.3785 , which means that the customer expectation was moderate because the minimum value was 1.00 and the maximum value was 5.00. Besides, there are small differences between values of customer expectation because the standard deviation was low (.73175). In addition, the mean value of perceived quality was 3.2655 . This means that the perceived quality was moderate because the minimum value was 1.00 and the maximum value was 5.00 , and the differences were small between the values of perceived quality because the standard deviation was low (.76057). Furthermore, the mean value of perceived value was 3.0339 , which means that the perceived value was moderate because the minimum value was 1.00 and the maximum value was 5.00. Besides, there are small differences between values of perceived value because the standard deviation was low (.87883). Finally, the mean value of corporate image was 3.1051. This means that the corporate image was moderate because the min imum value was 1.80 and the maximum value was 4.60 , and the differences were small between the values of corporate image because the standard deviation was low (.64355).

\subsection{Reliability of Variables and Me as urement}

The measurement of this study is adopted from previous studies which have been found to be reliable and valid. In this study, steps were taken to ensure that the measurement is still valid and re liable especially for different culture such as in Yemen, the current research setting. However, all measures obtained from 118 individuals $(\mathrm{N}=118)$ were subjected to reliability analys is to assess the dimensionality of the measurement scale. Scale reliability was assessed in terms of items-to-total correlation and Cronbach's alpha to determine the internal consistency of the measurement scale. Reliability, which is a type of association used to correlate a variable with itself, usually in assessing inter-rater similarity on a variable, is also discussed. Reliability is the correlation of an item, scale, or instrument with a hypothetical one which truly measures what it is supposed to. Cronbach's alpha is a measure of the inter correlation of items. If alpha is greater than or equal to .6, then the items are considered unidimensional and may be combined with an index or scale. Most of researchers use the more stringent cutoff criterion of 0.50 as suggested by[57]. Cronbach's alpha is the most common form of the internal consistency reliability coefficients. The table below shows the reliability of the items in this study.

According to[58], reliability is a matter of whether a particular technique, applied repeatedly to the same object, would yield the same result each time. The reliability of a measure is established by testing for both consistency and stability[59]; Table 4 indicates that all measurements exhibited high reliabilities with coefficient alphas ranging from 0.564 to 0.858 , exceeding or approaching the acceptable level of 0.50,[57]; in all cases. Therefore, all measurements were reliable and valid. 
Table 4. Reliability Statist ics for the variables

\begin{tabular}{|c|c|c|c|}
\hline \multicolumn{2}{|c|}{ Variable Name } & No of Items & Cron bach 's Alpha \\
\hline DV & Customer Satisfaction & $\mathbf{3}$ & .683 \\
\hline IV & Customer expectation & $\mathbf{3}$ & .801 \\
\hline IV & Perceived value & $\mathbf{2}$ & .564 \\
\hline IV & Perceived quality & $\mathbf{3}$ & .858 \\
\hline IV & Corporate image & $\mathbf{5}$ & .658 \\
\hline \multicolumn{2}{|c|}{} & $\mathbf{1 6}$ & \\
\hline
\end{tabular}

DV: dependent variable

IV: independent variables

Table 5. Correlations among the variables

\begin{tabular}{|c|c|c|c|c|c|c|}
\hline & & $\begin{array}{c}\text { Customer } \\
\text { satisfaction }\end{array}$ & Expectation & value & quality & image \\
\hline $\begin{array}{c}\text { Customer } \\
\text { satisfaction }\end{array}$ & $\begin{array}{c}\text { Pearson } \\
\text { Correlation } \\
\end{array}$ & 1 & & & & \\
\hline Expectation & $\begin{array}{c}\text { Pearson } \\
\text { Correlat ion }\end{array}$ & $.513(* *)$ & 1 & & & \\
\hline value & $\begin{array}{c}\text { Pearson } \\
\text { Correlation } \\
\end{array}$ & $.658(* *)$ & $.432(* *)$ & 1 & & \\
\hline quality & $\begin{array}{c}\text { Pearson } \\
\text { Correlation }\end{array}$ & $.663(* *)$ & $.649(* *)$ & $.690(* *)$ & 1 & \\
\hline image & $\begin{array}{c}\text { Pearson } \\
\text { Correlation }\end{array}$ & $.487(* *)$ & $.427(* *)$ & $.309(* *)$ & $.398(* *)$ & 1 \\
\hline
\end{tabular}

** Correlation is significant at the 0.01 level (2-tailed).

\subsection{Correlations among Variables}

The Pearson's correlation is used to measure the significance of linear bivariate between the independent and dependent variables. Variable association refers to a wide variety of coefficients which measure the strength of a relationship. Theoretically, the higher value of the correlation between two variables, the more related these variables are to each other (these values show the strength of relationships among variables). The direction of relationships among variables is another is sue that should be considered in analyzing the correlations between variables. A positive correlation indicates that the direction of the relationship is positive (if one increases, the other one increases). A negative correlation indicates an inverse relationship between variables (if one increases, the other one decreases). Bivariate Correlations is used to know the nature, direction and significance of the bivariate relationship of the variables of this study. Therefore, the researcher used the Bivariate Correlations procedure to compute Pearson's correlation coefficient. Table 5 shows the Pears on's correlation coefficient of the variables of the study. A rule of thumb is that multicollinearity may be a problem if a correlation is $>.90$, in the correlation matrix formed by all the independent variables[60].

Based on the analysis presented in Table 5 the results show that there is a positive correlation between the variables, the correlation between customer satis faction and customer expectation, indicates that there was a significant correlation between two variables with coefficient correlation $\mathrm{r}=.513$ at $\mathrm{p}<0.01$ level. In addition, there was a significant correlation between customer satisfaction and perceived value, $\mathrm{r}=.658$ at $\mathrm{p}<0.01$ level. The research result presents that there was a significant correlation between customer satisfaction and perceived quality, $r=.663$. at $\mathrm{p}<0.01$ level. As the result shows, there was a significant correlation between corporate image and customer satisfaction, $r=.487$. at $p<0.01$ level. Furthermore, the result shows that, there was a significant correlation between customer expectation and perceived quality, with the coeffic ient correlation $r=.649$. at $p<0.01$ level. It was found that there was a significant correlation between customer expectation and perceived value, the coefficient correlation is $\mathrm{r}=.432$ at $\mathrm{p}<0.01$ level. In addition, there was a significant correlation between customer expectation and corporate image, $(r=.427$ at $\mathrm{p}<0.01$ level $)$. In addition, the correlation between perceived value and perceived quality shows significant result that is $r=.690$. at $p<0.01$ level. Based on the analysis, it can be seen that there was a significant correlation between perceived value and corporate image, $r$ $=.309$. at $\mathrm{p}<0.01$ level. The coefficient correlation $\mathrm{r}=.398$ at $\mathrm{p}<0.01$ level indicates that there was a significant correlation between corporate image and perceived quality.

\subsection{Regression Analysis}

The multiple regression analysis determines which variables (independent variables) explain variability in the 
outcome, how much variability in the dependent variables is explained by the independent variable (s), and which variables are significant (over other variables) in explaining the variability of the dependent variable. Multip le regression estimates the coefficients of the linear equation, involving one or more independent variables that best predict the value of the dependent variable. In order to achieve the objective of this study, (there is a positive relationship between customer expectation, perceived quality, perceived value and corporate image with customer satisfaction among mobile service providers in Yemen), multiple regressions were used to study the effect of the independent variables (X1= customer expectation, $\mathrm{X} 2=$ perceived value, $\mathrm{X} 3=$ perceived quality, $\mathrm{X} 4=$ corporate image) to dependant variable ( $\mathrm{Y}=$ customer satisfaction). Significance level for customer expectation, perceived quality and perceived value are accepted on Alpha $(\alpha)=1 \%$, significance level $=99 \%$ significant at $1 \%(*)$. Table 6 shows the analys is of multip le regressions. The value of $\mathrm{R}$ was (.757), the value of $\mathrm{R}$ square was (.573) and the standard error of the estimate was (.45477). The model summary and the data are shown in Table 6

Table 6. Model Summary of regression analysis

\begin{tabular}{|c|c|c|c|c|}
\hline Model & $\mathrm{R}$ & R Square & $\begin{array}{c}\text { Adjusted R } \\
\text { Square }\end{array}$ & $\begin{array}{c}\text { Std. Error of } \\
\text { the Estimate }\end{array}$ \\
\hline 1 & $.757(\mathrm{a})$ & .573 & .558 & .45477 \\
\hline
\end{tabular}

a Predictors: (Constant), image, value, Expection, quality

b Dependent Variable: DV(customer satis faction)

The results from Table 6 show that the regression equation explains more than $57.3 \%$ of the variability in customer satisfaction. This is an acceptable level for $\mathrm{R}^{2}$ in explaining variability of customer satisfaction. The results of the multiple regression models indicate that customer expectation, perceived quality, perceived value and corporate image expla in the variance in customer satisfaction.
The value of the $R^{2}$ ( $R$ Square) is an acceptable value for explaining variability of customer satisfaction. Analys is of variance test statistics (ANOVA) indicates that the model is significant at $\alpha=0.000$. Table 4.6 provides the information on the significance of the model indicating a significant p-value of 0.000. The A VOVA findings are shown in Table 7 below.

Table 7 shows the ANOVA findings that the independent variables as a whole have significant relationships with customer satisfaction $(\mathrm{F}=37.873)(\mathrm{Sig} 0.000)$. Furthermore, this result is supported by the significant correlation among the variables. The findings show that the multiple regression coefficients for all independent variables with customer satisfaction is $R(.757)$ and $R$ square (.573). The number of independent variables relative to the sample size influences $\mathrm{R}$ square. The adjusted $\mathrm{R}$ square becomes smaller as fewer observations per independent variable are made. It reflects the decreasing ratio of estimated coefficients to the sample size and compensates for (Over fitting) of the data as R square increases (Hair, et. al., 2006). As shown in Table 8 the Collinearity Statistics VIF result for customer expectation = 1.837 , perceived value $=1.916$, perceived quality $=2.713$, and corporate image $=1.266$. These results are significant and acceptable complying with standard requirement value for Collinearity Statistics VIP of less than 10, standard requirement VIF $<10$ (Coake and Steed, 2007).

Table 8 shows that all the values of the T-statistic are significant. Thus, all the independent variables can be retained in the model. In other words, these variables can explain the change in customer satisfaction. Table 8 shows that three independent variables were found to be very significant and supportive of the hypotheses regression analysis except one of the customer expectation was not statistically significant and it does not supported the hypothesis.

Table 7. ANOVA

\begin{tabular}{|c|c|c|c|c|c|c|}
\hline Model & & Sum of Squares & Df & Mean Square & F & Sig. \\
\hline \multirow{4}{*}{1} & Regression & 31.331 & 4 & 7.833 & 37.873 & $.000(\mathrm{a})$ \\
\cline { 3 - 8 } & $\begin{array}{c}\text { Residual } \\
\text { Total }\end{array}$ & 23.370 & 113 & .207 & & \\
\cline { 3 - 8 } & & 54.702 & 117 & & & \\
\hline
\end{tabular}

a Predictors: (Constant), image, value, Expectation, quality

b Dependent Variable: DV

Table 8. Coefficients

\begin{tabular}{|c|c|c|c|c|c|c|c|c|}
\hline \multirow{2}{*}{\multicolumn{2}{|c|}{ Model }} & \multicolumn{2}{|c|}{$\begin{array}{l}\text { Unstandardized } \\
\text { Coefficients }\end{array}$} & \multirow{2}{*}{$\begin{array}{c}\begin{array}{r}\text { Standardized } \\
\text { Coefficients }\end{array} \\
\text { Beta }\end{array}$} & \multirow[t]{2}{*}{$\mathrm{t}$} & \multirow[t]{2}{*}{ Sig. } & \multicolumn{2}{|c|}{ Collinearity Statistics } \\
\hline & & B & Std. Error & & & & Tolerance & VIF \\
\hline \multirow[t]{5}{*}{1} & (Constant) & .302 & .245 & & 1.233 & .220 & & \\
\hline & Expectation & .080 & .078 & .085 & 1.021 & .310 & .544 & 1.837 \\
\hline & value & .288 & .066 & .370 & 4.344 & .000 & .522 & 1.916 \\
\hline & quality & .234 & .091 & .261 & 2.574 & .011 & .369 & 2.713 \\
\hline & image & .247 & .074 & .232 & 3.355 & .001 & .790 & 1.266 \\
\hline
\end{tabular}

a Dependent Variable: DV(customer satis faction) 
Multiple regression analys is in Table 8 was employed to determine whether customer expectation has an effect on cus tomer satisfaction; the result of regression analys is revealed that there was no significant relationship between customer expectation and customer satisfaction (.310); $\mathrm{B}=.080$. Because the significant value can't be met the requirement which is the value of significant should be less than 0.05 . Therefore, this hypothesis is rejected.

In contrast, the regression analysis as in Table 8 was employed to determine whether the perceived value has an effect on customer satis faction; the result of regress ion analys is revealed that there was a positive relationship between these two variables at the significance level $0.00 \mathrm{~B}=.288$ The correlation analys is for these variables showed a positive coefficient. Therefore, this hypothes is is accepted.

The multiple regression analys is as in Table 8 was employed to determine whether the perceived quality has an effect on customer satisfaction; the result of regression analys is revealed that there was a positive relationship between these two variables at the significance level (.011) with $\mathrm{B}=.234$. Therefore, this hypothesis is supported and met the requirement.

Finally, the multiple regression analys is in shows in Table 8 was employed to determine whether the corporate image has an effect on customer satisfaction; the result of regression analys is revealed that there was a positive relationship between these two variables at the significance level (.001); $\mathrm{B}=.247$. The hypothesis is accepted because the result of significance is less than 0.05 (Significance requirement standard $<0.05)$.

Based on the data of 118 respondents, the multi-items measures were subjected to a series of validity and reliability checks. The researcher explained the main findings, and hypotheses test to answer the research questions of this research. The findings reveal the profile of the respondents, correlation and all variables were correlated. This was followed by multiple regressions which tested all five variables, namely, independent variables (customer expectation, perceived quality, perceived value, and corporate image) with the dependent variable (customer satisfaction). The result of multiple regressions was all variables have positive significant relationship with the dependent variable except one of the independent variables namely customer expectation was not statistically significant and this hypothesis is rejected.

\section{Discussions}

The main method of this study is quantitative method in natural. This study was conducted to answer four research questions, which are; 1) is there any significant relationship between customers' perceived quality and customer satis faction? 2) Is there any significant relationship between customers' perceived value and customer satisfaction? 3) Is there any significant relationship between customers' expectation and customer satisfaction? 4) Is there any significant relationship between corporate image and customer satisfaction? This study also aimed to test four main hypotheses on the relationships between customer expectation, perceived value, perceived quality, corporate image and customer satisfaction. Table 9 summarizes the study's findings by listing the hypothesized results and whether they are supported or rejected, followed by discussion of the questions.

Table 9. the Summary of Hypotheses Results

\begin{tabular}{|c|c|}
\hline Hypotheses & Results \\
\hline $\begin{array}{c}\mathbf{H}_{1}: \text { There is a positive/significant relationship } \\
\text { between the perceived quality and customer } \\
\text { satisfaction. }\end{array}$ & Accepted \\
\hline $\begin{array}{c}\mathbf{H}_{2}: \text { There is a positive/significant relationship } \\
\text { between the perceived value and customer } \\
\text { satisfaction. }\end{array}$ & Accepted \\
\hline $\begin{array}{c}\mathbf{H}_{3}: \text { There is a positive/significant relationship } \\
\text { between the customer expectations and customer } \\
\text { satisfact ion. }\end{array}$ & Rejected \\
\hline $\begin{array}{c}\mathbf{H}_{4}: \text { There is a positive/significant relationship } \\
\text { between the corporate image and customer } \\
\text { satisfact ion. }\end{array}$ & Accepted \\
\hline
\end{tabular}

Out of the four hypothesized relationships, all were positively related to customer satisfaction. But only three factors (perceived value, perceived quality, and corporate image) of this hypothes is are statistically significant at a 5\% confidence level, unlike customer expectation that is not statistically significant, although it supports the positive relationship as hypothesized. Very important in this study is that the data significantly fits the model with R (.573) a good indication that $57 \%$ of the variance in customer satisfaction is explained by the independent variables (perceived value, perceived quality, corporate image and customer expectation) as hypothesized above in table 9 and were tested by using multip le regressions.

The first research question in this study is there any significant relationship between perceived quality and customer satisfaction?' By using the hypotheses, there is a positive/significant relationship between the perceived quality and customer satisfaction. The result of this hypothesis showed that the mobile service providers in Yemen have a strong and positive significant relationship with the customer satisfaction. Thus, this result shows that, the hypotheses met the requirement and is accepted. This result confirmed the previous studies that found a positive relationship between the service quality and customer satis faction[61],[37].

The second research question is there any significant relationship between customers' perceived value and customer satisfaction? By using the hypotheses stated that, there is a positive/significant relationship between the perceived value and customer satisfaction the results shows perceived value is more relevant to customer satisfaction, and it was positively significant relationship with customer satisfaction, thus this hypothes is is supported. However, this finding was actually confirming the previous studies such 
as[39];[53],[16],[17].

The third research question is stated as is there any significant relationship between customers' expectation and customer satisfaction? By using the hypothes is stated there is a positive significant relationship between the customer expectations and customer satisfaction. The results of multiple regression of this hypothesis show that was not statistically significant with the customer satisfaction, This finding was similar with the previous studies which indiacted that there was no signifacnt relationhsip between the customer expectation and the customer satisfaction[52].

Finaly, the fourth research question is is there any significant relationship between corporate image and customer satisfaction?' The hypothes is stated there is a positive/significant relationship between the corporate image and customer satisfaction. The result of this hypothes is showed that, there was a positive significant relationship between corporate image and customer satisfaction. The $\mathrm{R}^{2}$ is .237 , which explains about $23.7 \%$ of the customer satisfaction with mobile service providers in Yemen. This means that this hypothesis is accepted, and confirms the previous studies such as by[20],[53].

However, the result of correlation, and multiple regressions in assessing the variables or the empirical relationship between perceived values, perceived quality, and corporate image were positively related to customer satisfaction as hypothesized. These factors have explained about $\mathrm{R}^{2}=.573$ in the depended variables customer satisfaction therefore, this finding is quite strong because it is cover about $57 \%$ of the customer satisfaction in among the Yemeni customer mobile service .

All the four objectives of this study investigated the relationship between perceived value, perceived quality, customer expectation, and corporate image, which have a significant positive direct influence on customer satisfaction. Only one of the four independent variables namely customer expectation has positive and not statistically significant relation to customer satisfaction. Therefore, this finding had answered all research questions and objectives as well as supported the hypotheses except one. This study confirmed the influence between perceived value, perceived quality, and corporate image to customer satisfaction.

\section{Conclusions}

As competition is increasing among the companies, especially in the mobile market today, this market has become extremely competitive and the service providers are moving aggressively to attract customers by offering attractive promotions and services. Therefore, the service providers should take the necessary action for them to know the effects that will make customers satisfied in order to be able to retain customer loyalty in the telecommunications service. The findings of th is research are very informative for mobile operators, especially the Yemeni mobile service providers. The results indicate that perceived quality, perceived value and corporate image have high effect on customer satisfaction. This finding describes these factors as the driving force for achieving customer satisfaction in the Yemen mobile service market, and the manager should consider these factors in order to attain high customer satisfaction, which will lead to customer retention.

\section{REFERENCES}

[1] Dunnewijk, T. and S. Hultén (2007). "A brief history of mobile communication in Europe." Telematics and Informatics 24(3): 164-179.

[2] Lonergan, D., W. Swain, et al. (2004). "Asia-Pacific Region to drive global wireless revenue." The Yankee Group Report, Boston,_MA, USA.

[3] ITU "World Telecommunications Indicators," International Telecommunications Union. Available online at http://www. itu.int/ITU-D/ict/statistics, 2003.

[4] Albrecht, K., \& Zemke, R. (1985). Service America. Homewood, IL: Dow Jones-Irwin.

[5] www.mtn-investor.com/reporting/presentations/mena_2007/ yemen.pdf

[6] http://www.sabafon.com/?lang=en-US

[7] http://www.yemenmobile.com.ye/index.php?lng=english

[8] http://www.mtn.com.ye/eng/index.html

[9] http://www.y-gsm.com/

[10] Totel Report(2009)http : www.totel.com.au/yemen-telecom munications-research.asp.

[11] Al-Haidary (2007), http://www.foreignaffairs.com/files/attac hments/YemenFAlow_0.pdf

[12] Agarwal, S., M. Erramilli, et al. (2003). "Market orientation and performance in service firms: role of innovation." Journal of Services Marketing 17(1): 68-82.

[13] Fournier, S. and D. Mick (1999). "Rediscoveringsatisfaction. " The Journal of Marketing: 5-23.

[14] Reichheld, F. (1996). "Learning from customer defections." Harvard Business Review 74: 56-70.

[15] Anderson, E., C. Fornell, et al. (1994). "Customer satisfaction, market share, and profitability: findings from Sweden." The Journal of Marketing: 53-66.

[16] McDougall, G. and T. Levesque (2000). "Customer satisfaction with services: putting perceived value into the equation." Journal of Services Marketing 14(5): 392-410.

[17] Turel, O. and A. Serenko (2006). "Satisfaction with mobile services in Canada: An empirical investigation." Telecommunications Policy 30(5-6): 314-331.

[18] Pizam, A. and T. Ellis (1999). "Customer satisfaction and its measurement in hospitality enterprises." Management 326: 339 .

[19] Andreassen, T. and B. Lindestad (1998). "Customer loyalty and complex services." International Journal of Service 
Industry Management 9(1): 7-23.

[20] Gronholdt, L., A. Martensen, et al. (2000). "The relationship between customer satisfaction and loyalty: cross-industry differences." Total Quality Management \& Business Excellence 11(4): 509-514.

[21] Yemen Polling Center (YPC) Market Research Unit(2010) http://www.y emenpolling.com/index.php?action=showSecti on\&id $=2$

[22] Lim, H., R. Widdows, et al. (2006). "M-loyalty: winning strategies for mobile carriers." Journal of Consumer Marketing 23(4): 208-218.

[23] Backlund, G. and M. Holmqvist (2006). "Exceeding customer expectations: an online and offline perspective."

[24] Sendecka L, Nysveen H (2004) "Adoption of mobile services Moderating effects of service's information intensity" NORGES HANDELSHØYSKOLE Bergen, spring 2006.

[25] Henkel, D., N. Houchaime, et al. (2002). The Impact of Emerging WLANs on Incumbent Cellular Service Providers in the US.

[26] Fornell, C. (1992). "A national customer satisfaction barometer: the Swedish experience." The Journal of Marketing: 6-21.

[27] Hill, N. and J. Alexander (2000). Handbook of customer satisfaction and loyalty measurement, Gower Publishing Company.

[28] Jones, Thomas O. and W. Earl Sasser (1995), "Why satisfied customer defects?", Harvard Business Review, November December, 88-99.

[29] Reichheld, F.F. (1996) - The Loyalty Effect, Harvard Business School Press, Boston, MA.

[30] Heskett, J., W. Sasser, et al. (1997). The service profit chain: How leading companies link profit and growth to loyalty, satisfaction, and value, Free Pr.

[31] Oliver, R.L. (1977) - "Effects of expectation and disconfirmation on post-exposure product evaluations: an alternative interpretation", Journal of Applied Psychology, Vol. 62 No. 4, pp. 480-86.

[32] Olson, J. C. and P. A. Dover (1979). "Disconfirmation of consumer expectations through product trial." Journal of Applied Psychology 64(2): 179-189.

[33] Tse, D. K. and P. C. Wilton (1988). "Models of consumer satisfaction formation: an extension." Journal of Marketing Research 25(2): 204-212.

[34] Vavra, T. (1997). Improving your measurement of customer satisfaction: A guide to creating, conducting, analyzing, and reporting customer satisfaction measurement programs, Asq Pr.

[35] Parker, C. and B. Mathews (2001). "Customer satisfaction: contrasting academic and consumers' interpretations." Planning: 3844.

[36] Sureshchanndra, G. S., Rajendran, C. \&Anantharaman, R. N. (2003). "The relationship between service quality and customer satisfaction - a factor specific approach". Journal of Service Marketing, 16 (4), 363-379.

[37] Serkan, A., Göekhan, Ö., \& Öemer, A. 2005. Customer loyalty and the effect of switching costs as a moderator variable: A case in the Turkish mobile phone market. Marketing Intelligence \& Planning, 23(1): 89-103.

[38] Zeithaml, V., M. Bitner, et al. (1996). Services marketing, McGraw-Hill New York.

[39] Fornell, C., M. Johnson, et al. (1996). "The American customer satisfaction index: nature, purpose, and findings." The Journal of Marketing: 7-18.

[40] Oliver, R. (1993). "Cognitive, affective, and attribute bases of the satisfaction response." Journal of Consumer Research 20(3): 418.

[41] Dabholkar, P., D. Thorpe, et al. (1996). "A measure of service quality for retail stores: scale development and validation." Journal of the Academy of Marketing Science 24(1): 3-16.

[42] Hurley, R. and H. Estelami (1998). "Alternative indexes for monitoring customer perceptions of service quality: a comparative evaluation in a retail context." Journal of the Academy of Marketing Science 26(3): 209-221.

[43] NQRC (1995), American Consumer Satisfaction Index Methodology Report, University of Michigan Business School, Ann Arbor, MI.

[44] Barnhoorn,C. (2006). Customer satisfaction increases in the Telecommunications industry. Synovate Research Reinvented

[45] Anckar, B., C. Carlsson, et al. (2003). Factors affecting consumer adoption decisions and intents in mobile commerce: Empirical insights. Proceedings of the 16th Bled Electronic Commerce Conference.

[46] Heinonen, K. (2004). "Reconceptualizing customer perceived value: the value of time and place." Managing Service Quality 14(2/3): 205-215.

[47] Langley, C. and M. Holcomb (1992). "Creating logistics customer value." Journal of Business Logistics 13: 1-1.

[48] Cottet, P., M. Lichtle, et al. (2006). "The role of value in services: a study in a retail environment." Journal of Consumer Marketing 23(4): 219-227.

[49] Zeithaml, V. (1988). "Consumer perceptions ofprice, quality, and value: a means-end model and synthesis of evidence." The Journal of Marketing 52(3): 2-22.

[50] Ravald, A. and C. Gronroos (1996). "The value concept and relationship marketing." European Journal of Marketing 30(2): 19-30.

[51] Anderson, E. W. and C. Fornell (2000). "Foundations of the American customer satisfaction index." Total Quality Management \& Business Excellence 11(7): 869-882.

[52] Turkyilmaz, A. and C. ' $\notin$ ? zkan (2007). "Development of a customer satisfaction index model: An application to the Turkish mobile phone sector." Industrial Management and Data Systems 107(5): 672.

[53] Johnson, M. D., A. Gustafsson, et al. (2001). "The evolution and future of national customer satisfaction index models." Journal of Economic Psychology 22(2): 217-245.

[54] Nguyen, N., and Leblanc, G. (2001). Corporate image and corporate reputation in consumers' retention decision in services. Journal of retailing and Consumer Services, 8(3), 227-236.

[55] Sekaran, U. (2003). Research methods for business (4th ed.). 
Hoboken, NJ: John Wiley \& Sons.

[56] Coakes, S. J. and L. G. Steed (2007). SPSS: Analysis without anguish: Version 14.0 for windows, John Wiley \& Sons Australia.

[57] Kaiser, H. F. and J. Rice (1974), "Little jiffy, mark IV." Educational and psychological measurement 34(1): 111.

[58] Babbie, E. (1998). "Survey research methods." Belmont CA.
[59] Cavana, R., B. Delahaye, et al. (2001). "Applied business research." Qualitative and Quantitative Methods, Milton, Australia.

[60] Hair, J.F., Black, W.C., Babin, A.L., Tatham, R.L. (2006) Multivariate Data Analysis. 6 Th Edition. Pearson Prentice Hall. Upper Saddle River, New Jersey.

[61] Palkar, A. (2004). "Determinants of Customer Satisfaction for Cellular Service Providers." Sinhgad Institute of Management and Computer Applications 28(1): 1-10. 